ISSN 1392-3196 / e-ISSN 2335-8947

Zemdirbyste-Agriculture, vol. 103, No. 4 (2016), p. 391-396

DOI $10.13080 /$ z-a.2016.103.050

\title{
Microbiological changes and severity of decay in apples stored for a long-term under different storage conditions
}

\author{
Karina JUHNEVICA-RADENKOVA, Vitalijs RADENKOVS, Dalija SEGLINA \\ Institute of Horticulture, Latvia University of Agriculture \\ Graudu 1 Dobele, Latvia \\ E-mail: vitalijs.radenkovs@lvai.lv
}

\begin{abstract}
Apples occupy most of the Latvian vegetable market, nevertheless there is a lack of good quality locally grown apples. Using advanced storage technologies, such as storage in controlled atmosphere in ultra low oxygen $\left(\mathrm{O}_{2}\right)$ (ULO) and elevated carbon dioxide $\left(\mathrm{CO}_{2}\right)$ conditions, as well as pre-treatment of fruits with 1-Methylcyclopropene (1-MCP) will substantially improve the quality of fruits and globally assist apple growers to distribute more qualitative and safe fruits on the local market. The aim of the study was to ascertain the causes of apple decay that occurred during storage under different conditions. Two apple storage technologies were tested in this study: cold storage under conventional conditions + 1-Methylcyclopropene treatment and controlled atmosphere $-2.0 \% \mathrm{CO}_{2}$, $1.0 \% \mathrm{O}_{2}$ (ULO1) and $2.5 \% \mathrm{CO}_{2}, 1.5 \% \mathrm{O}_{2}$ (ULO2) conditions. After apple storage for six months the following microscopic fungi were isolated: Penicillium expansum (30.44\%), Monilinia fructigena (26.08\%), Neofabraea alba $(21.73 \%)$, Colletotrichum acutatum $(13.04 \%)$, Botrytis cinerea $(8.69 \%)$ in cold storage, while P. expansum (35.26\%), Colletotrichum acutatum (23.57\%), Neofabraea alba (11.76\%), B. cinerea (11.76\%), M. fructigena $(11.76 \%)$ and Fusarium avenaceum $(5.89 \%)$ were isolated from fruits that prior to storage were pre-treated with 1-MCP. Apples that had been stored under ULO1 conditions predominantly were contaminated with: $N$. alba (33.34\%), M. fructigena (26.69\%), B. cinerea (13.33\%), P. expansum $(6.66 \%)$, F. avenaceum (6.66\%), Phomopsis/ Diaporthe eres $(6.66 \%)$ and Mucor circinelloides $(6.66 \%)$, while under ULO2: N. alba (33.33\%), M. fructigena $(33.33 \%), F$. avenaceum $(16.67 \%)$ and P./D. eres $(16.67 \%)$. Diversity of microscopic fungi, which were isolated from differently stored and decayed apple samples, was quite similar, though with insignificant difference. For instance, microscopic fungus $F$. avenaceum was not found only in cold storage kept fruits, while microscopic fungus of the genus P./D. eres was identified when apples were stored under ultra low oxygen conditions.
\end{abstract}

Key words: apple fruit, controlled atmosphere, cultivar, 1-Methylcyclopropene, microbiological contamination.

\section{Introduction}

A short storage life of apples could be explained by the various reasons, the main one is microscopic fungi that retain their biological activity even after apple harvesting, thus limiting the storage time. Depending on the species of microscopic fungi they can start to develop during apple vegetation or after harvesting. Presence of such microscopic fungi is difficult to identify prior to storage as the first most common symptoms of infection appear only during storage.

Most common microscopic fungi that can be present on the surface of apples cause certain types of spoilage. Typical spoilage that can take place during apple storage is rot and moulds. The literature describes several rot agents that have been isolated from spoiled apples (Juhneviča et al., 2011; Juhnevica-Radenkova et al., 2016). They can be as a single source of infection or can create a complex of infections.

Colletotrichum gloeosporioides causes apple decay, wounds and dead skin fragments. Initial signs of infected fruits are circular rot spots with concentric different in size brown shades. Spore masses are bright orange or yellow (Ellis, 2008).

Neofabraea spp. earlier was known as Gloeosporium spp., Cryptosporiopsis spp. and Plychtaena spp. Neofabraea spp. predominantly exists as a saprophyte on dead and defective bark. Infection occurs during vegetation period, as well as in post-harvest storage from the pathogen spores. Usually, lesions are circular or oval in shape, pale brown spots with a darker outer ring. The rotten tissues usually are relatively firm, acervulus are frequently present in old lesions under humid conditions (Neri et al., 2009).

Monilinia laxa, M. fructigena and M. fructicola cause brown rot damage on fruits, the fungus can also infect leaves, blossoms, as well as shoots. Infection most commonly remains over winter on mummified fruits, on the ground, and in cankers. Infected fruits turn brown and soft (Tahir, 2006).

Botrytis cinerea predominantly occurs in fruits mechanically injured at harvest. $B$. cinerea commonly colonises shoots, leaves and fruit peel. Secondary infection can also occur during long-term storage of fruits through fruit-to-fruit contact and can cause considerable losses. It is caused by high relative humidity in storage chambers.

Penicillium expansum and $P$. digitatum predominantly occur in fruits that had been mechanically injured during harvesting or in fruit tissue that had been previously injured by different fungi. There is evidence that apples injured (peel and internal injuries) during harvesting will be susceptible to colonisation by $P$. expansum and $P$. digitatum pathogenic fungi (Tahir, 2006).

The action of microscopic fungi can be suppressed using fungicides and ethylene inhibitors such as 1-Methylcyclopropene (1-MCP). However, application of $1-\mathrm{MCP}$ in organic farms is prohibited. Since organic growers stay away from synthetic fertilization and 
fungicide treatment, they have more intensive fruit decay that causes fruit yield losses (Tahir, 2006). The data found in the scientific literature suggest that Swedish organic orchard had $20 \%$ more apples damaged by microscopic fungi compared to conventional orchard (Jönssson et al., 2010). Another important storage technique that has great advantages is ultra low oxygen storage (JuhnevicaRadenkova et al., 2016). This type of storage is essentially based on delaying the ripening processes by controlling the level of gases around fresh fruits and vegetables (Tahir, 2006). Ultra low oxygen storage may substantially reduce the possible development of microorganisms and limit the possible infection of healthy fruits (Juhneviča et al., 2011). Along with delaying ripening processes, respiration rate of fruits also can be suppressed; as a result fruit storability can be improved and quality maintained. Due to high carbon dioxide $\left(\mathrm{CO}_{2}\right)$ level in a storage room, antimicrobial properties of this compound can also be observed (Tahir, 2006).

It is well known that apple decay can also be associated with physiological disorders. Nowadays, there are eight types of physiological disorders, which have different causes. For instance, bitter pit is a physiological disorder of apples that is related to calcium deficiency in fruit. Water core (particularly apple cultivars 'Tiina' and 'Zarja Alatau') is a physiological disorder that is associated with a high sorbitol concentration in fruits. There are cultivars that are susceptible to flesh browning, usually associated with water core at harvest, brown heart and also core breakdown. Another important physiological disorder is apple rust which is particularly associated with meteorological conditions during apple ripening. Superficial scald is a physiological disorder causing brown or black patches on apple fruit skin that appears during storage. Superficial scald is primarily associated with insufficient storage conditions and particularly with ventilation intensity.

Types of storage, incorrect storage temperature and concentration of protective gases in storage chambers have a great influence on the development of physiological disorders. Flesh browning is the most frequent physiological disorder that causes significant losses during apple storage (associated with low temperature during storage) and superficial scald (associated with low $\mathrm{CO}_{2}$ concentration during storage). Flesh browning symptoms during cold storage appear in the cortex (diffuse) or vascular tissue (radial) like patches around the flesh. During apple storage, progressing diseases and premature apple harvesting can contribute to the faster development of this disorder. Flesh browning disorders of apples often are cultivar specific. For instance, apple cultivars 'Ligita' and 'Liivika' are very susceptible to this disorder. Superficial scald is a worldwide distributed physiological disorder that has a great effect on external quality of apples. Apples harvested at earlier stages have more prevalent superficial scald incidence. Susceptibility of cultivars 'Sinap Orlovkij' and 'Edite' apples is high. Scientific papers indicate that at least partial control of the disorder can be achieved from application of antioxidants, especially the commonly used diphenylamine (DPA) or using technologies that provide low oxygen concentration during storage (Calvo, 2010). Therefore, control of temperature and concentration of gases in storage chambers is important not only during storage but also shelf-life period (Juhnevica-Radenkova et al., 2014).

The aim of study was to ascertain the causes of apple decay that occurred during storage under different conditions.

\section{Material and methods}

Research time and place. The research was carried out during the period from 2012 to 2014. The studies were conducted at the Experimental Processing
Department of the Latvia State Institute of Fruit-Growing (at present - Institute of Horticulture, Latvia University of Agriculture) in Dobele and at the Laboratory of Microbiology, Faculty of Food Technology, Latvia University of Agriculture. The number of damaged fruits for each cultivar during storage was counted and apple rotting agents analysed according to the morphological features and DNA sequences (Juhneviča et al., 2011; Volkova et al., 2013). Sequencing analyses were performed at Latvian Plant Protection Research Centre.

Materials used for research. Duration of the experiment was six months. Apples were analysed before storage and after six months of storage. The following apple cultivars were chosen for experiments: autumn cultivars 'Auksis', 'Orlik' and 'Gita', harvested twice in 2012 (06 09 and 1109 ) and in 2013 (10 09 and 14 09), and winter cultivars 'Antej', 'Belorusskoje Malinovoje', 'Sinap Orlovskij' and 'Zarja Alatau', harvested twice in 2012-2013 (28 09 and 03 10) and in 2013-2014 (14 09 and 2109 ). Apples were harvested at the technical stage of maturity, assessed by starch content using Starch iodine test (Drudze, 2005) that characterizes the degree of fruit ripeness.

Structure of the research. Shortly after harvesting apples were air-cooled for 24 hours in a cooling chamber at a temperature of up to $+4 \pm 0.5^{\circ} \mathrm{C}$. From each cultivar 40 fruits were selected, their average weight was $\sim 6 \mathrm{~kg}$. For each storage technology, the same amount of apples was prepared. Then the samples were placed in polypropylene boxes with perforated walls. The cooled down apple samples were divided into four groups for post-harvest storage: 1) cold storage (control) - apple storage was implemented under traditional conditions at an air temperature of $+2 \pm 1{ }^{\circ} \mathrm{C}$ and relative humidity of $85 \% ; 2$ ) cold storage +1 -Methylcyclopropene (1-MCP) treatment; 3) ultra low oxygen (ULO1) - $\mathrm{O}_{2} 1.00 \%, \mathrm{CO}_{2}$ $2.00 \%$; 4) $\mathrm{ULO} 2-\mathrm{O}_{2} 1.50 \%, \mathrm{CO}_{2} 2.50 \%$. Storage in ULO was implemented by "Fruit Control Equipment" (Italy), selecting two different gas compositions in the mixture of controlled atmosphere.

Fruit treatment with 1-Methylcyclopropene $(1-M C P)$. The treatment with ethylene inhibitor 1-MCP was performed in an air-tight fruit processing container. The ethylene action inhibitor 1-MCP was purchased from "RandH" (Rohm and Haas Company, Italy). The material consists of a homogeneous mixture of $1-\mathrm{MCP}$ at a concentration of $3.3 \%$ together with related manufacturing impurities, in the form of a complex with alpha-cyclodextrin, together with any other necessary co-formulants. 1-MCP powdery substance was dissolved in warm water $+50 \pm 2^{\circ} \mathrm{C}$ by ratio of 1 -MCP to water as $1: 30$, the concentration of the obtained solution was $0.625 \mu 1 \mathrm{~L}^{-1}$. This ratio was chosen based on the wellfounded scientific research of Polish researchers affirming the above-mentioned concentration as more suitable for apple treatment with 1-MCP (Wawrzynczak et al., 2007). The solution was prepared in an Erlenmeyer flask, which was subsequently placed in an air-tight processing container with apples intended for storage. Based on 1-MCP manufacturer's recommendations in a room capacity of $0.5 \mathrm{~m}^{3}$ the amount of 1-MCP preparation could be $0.5 \mathrm{~g}$. The treatment with 1-MCP was performed at a temperature of $18 \pm 1^{\circ} \mathrm{C}$ in an air-tight fruit processing container for $24 \mathrm{~h}$. After treatment, fruit samples were stored in cold storage under conventional conditions. The apples treated with 1-MCP and untreated (control) were stored in the same conditions but on different pallets.

Detection of apple deterioration agents microscopic fungi. Detection of apple lesions was performed using the method of moist chamber. Damaged apples separately from each other were placed in a plastic box with a lid. A pad of filter paper soaked with distilled water was placed in the box base under apples. The 
samples were stored for 14 days at a temperature of +25 $\pm 1^{\circ} \mathrm{C}$ in variable daily light and darkness mode (natural conditions $-12 \mathrm{~h}$ of dark and $12 \mathrm{~h}$ of light). After typical sporulation of microscopic fungi on damaged areas of apple surface, pure cultures of microscopic fungi were developed for molecular analysis. The rDNA (ribosomal deoxyribonucleic acid) was isolated from pure culture to determine taxonomic status. Internal transcribed space (ITS) region using a polymerase chain reaction (PCR) was analyzed by combination of universal primers ITS $1 \mathrm{~F}$ and ITS4 (standard for Ascomycota), sequencing and following sequence comparison with the NCBI GeneBank database (Volkova et al., 2013).

Statistical analysis. The processing of data was carried out by the methods of mathematical statistics, where arithmetic average value, standard deviation and standard error were calculated using the software Excel 2007. Significant differences between the samples were calculated and analysed by the SPSS 20.0, using a two-factor analysis of variance (ANOVA), LSD test and Tukey's test. The significance of differences was determined at $p<0.05$.

\section{Results and discussion}

Results shown that significantly $(p<0.05)$ higher occurrence of disorders caused by apple decay was when apples were kept under cold storage conditions, from $9.76 \%$ to $88.10 \%$ ( $1^{\text {st }}$ harvesting) and from $6.50 \%$ to $100 \%$ ( $2^{\text {nd }}$ harvesting) (Table, research year 2012-2013). Whereas, severity of decay caused by pathological and physiological diseases in apples treated with 1-MCP was statistically less pronounced compared with cold storage: from $4.08 \%$ to $30.95 \%$ ( $1^{\text {st }}$ harvesting) and from $2.08 \%$ to $100 \%$ ( $2^{\text {nd }}$ harvesting). Decay of apple samples, which had been stored under controlled atmosphere conditions in ULO1, accounted for from $2.35 \%$ to $5.51 \%\left(1^{\text {st }}\right.$ harvesting) and from $3.21 \%$ to $100 \%$ ( $2^{\text {nd }}$ harvesting).

Apple samples those stored under ULO2 conditions were spoiled from $1.43 \%$ to $4.65 \%\left(1^{\text {st }}\right.$ harvesting) and from $0 \%$ to $100 \%$ ( $2^{\text {nd }}$ harvesting).

Analysis of the results obtained within research year 2013-2014 showed that spoilage of apple fruits stored in cold storage was from $12.23 \%$ to $100 \%\left(1^{\text {st }}\right.$ harvesting) and from 5.51 to $100 \%$ ( $2^{\text {nd }}$ harvesting). In turn, deterioration severity significantly $(p<0.05)$ decreased when apple samples prior to long-term storage were treated with 1-MCP. Apple decay accounted for from $5.32 \%$ to $100 \%$ ( $11^{\text {st }}$ harvesting) and from $3.22 \%$ to $100 \%$ ( $2^{\text {nd }}$ harvesting). Decay of apple samples, which had been stored under controlled atmosphere conditions in ULO1, accounted for from $3.15 \%$ to $5.65 \%$ ( $1^{\text {st }}$ harvesting) and from 1.32 to $100 \%$ ( $2^{\text {nd }}$ harvesting), while under ULO2 conditions decay of apples ranged from $1.54 \%$ to $5.01 \%$ ( $1^{\text {st }}$ harvesting) and from $1.95 \%$ to $100 \%$ ( $2^{\text {nd }}$ harvesting). The lowest deterioration severity of apples stored under controlled atmosphere conditions in ULO was associated with the reduced oxygen and increased carbon dioxide $\mathrm{CO}$, content that adversely affected the microbial growth and development. Similar observation has been made by the group of researchers from Brazil, pointing out that the best ultralow oxygen conditions for the storage of $\mathrm{cv}$. 'Royal Gala' apples is $1.0 \mathrm{kPa} \mathrm{O}$ combined with $2.0 \mathrm{kPa}$ of $\mathrm{CO}_{2}$ at $1.0^{\circ} \mathrm{C}$ (Weber et al., 2011). A group of researchers from Latvia stated that significantly lowest $(p<0.05)$ amount of microorganisms was found on apples that had been stored under controlled atmosphere (Juhneviča et al., 2011; Juhnevica-Radenkova et al., 2016).

Spoilage of apples stored in cold storage (control) was $48.96 \%$ (average data for all apple cultivars), while the lowest $(p<0.05)$ spoilage of apples was found when apple samples prior to cold storage had been treated with 1 -MCP - up to $21.62 \%$. In turn, deterioration severity of samples stored in ULO1 and ULO2 was 34.70\% and $9.91 \%$, respectively. As can be seen the highest deterioration intensity of apples was in cold storage, while the lowest in ULO2. The high intensity of apple decay in ULO1 can be associated with the physiological disorders, particularly with elevated concentration of carbon dioxide $\mathrm{CO}_{2}$. Describing the damage, which was caused by elevated concentration of $\mathrm{CO}_{2}$, scientists indicate that the main cause of this disorder is cultivar susceptibility (apples are very sensitive to high concentration of $\mathrm{CO}_{2}$ ). Disorder is associated with high relative humidity in storage chambers (humidity should be reduced gradually), high initial concentration of $\mathrm{CO}_{2}$ as well as delayed cooling after harvesting (Watkins, Lui, 2010).

During six months of cold storage (control) apples of cvs. 'Gita', 'Orlik', 'Zarja Alatau', 'Auksis' and 'Belorusskoje Malinovoje' were removed from the research due to non conformity to requirements.

The poor quality of cvs. 'Orlik' and 'Gita' apples was related to over ripening, but fruits of cvs. 'Auksis' and 'Zarja Alatau' had pronounced softening. Signs of scab were also observed on the surface of cv. 'Belorusskoje Malinovoje' fruits.

Physiological disorders of cvs. 'Orlik' and 'Gita' apples stored under cold storage + 1-MCP treatment were associated with the over ripening, while apples stored under controlled atmosphere conditions (ULO1) had obvious signs of $\mathrm{CO}_{2}$ injury.

During the experiment microscopic fungi were found on the surface of apples that were stored in cold storage (control). Those fruits had visible signs of spoilage (Fig. A) caused by P. expansum (30.44\%). Most frequently blue mold caused by the $P$. expansum was detected on the surface of apples with mechanically injured tissue.

In accordance with the report provided by the group of researchers it is evident that the fungus, $P$. expansum, not only causes fruit decay but also produces the carcinogenic fungal metabolite called patulin. This fungal metabolite may exibit a number of toxic effects both in humans and animals and its presence in food products is undesirable (Barreira et al., 2010).

During storage of apples for six months, $26.08 \%$ of all the microorganisms located on the surface of apples were Monilinia fructigena. Brown rot caused by this fungus is a major post-harvest disease of pome and stone fruits worldwide (Janisiewicz et al., 2010). Infection by the microscopic fungus occurs during blooming, then for a long period of vegetation remains latent and after fruit harvesting, during 24-48 hours begins the stage of development (Spadoni et al., 2013). In the current research, most frequently it was isolated from the apples of cvs. 'Antej' and 'Auksis'. Scientists believe that development of $M$. fructigena can be suppressed by use of fruit storage under controlled atmosphere (Karabulut, Baykal, 2004), as well as hot water treatment at $48^{\circ} \mathrm{C}$ temperature for 12 minutes (Jemric et al., 2011). Liu et al. (2012) observed a statistically positive effect, achieved when fruits were subjected to heat-treatment at $40^{\circ} \mathrm{C}$ temperature for 10 minutes.

Neofabraea alba is routinely described as an important cause of apple spoilage in various European countries. Fruit infection occurs in the orchard, but the disease symptoms appear only several months after harvest (Neri et al., 2009). Figure (A) shows that $21.73 \%$ of apples were damaged directly by $N$. alba and more pronounced lesions were found in cvs. 'Antej', 'Zarja Alatau', 'Belorusskoje Malinovoje' and 'Gita' apples. As it was mentioned above, the infection occurs already in the orchard but some symptoms appear during 3-4 months of cold storage, when numerous lesions can develop on a single fruit. Fungi generally live as saprophytes on dead bark, pruning snags and leaves of pome fruits. The main disease symptoms appear only when the fruit is ready to eat (Neri et al., 2009). The 
Table. Percentage (\%) of damaged apples after six months of storage

\begin{tabular}{|c|c|c|c|c|c|}
\hline \multirow{3}{*}{ Cultivars } & \multirow{3}{*}{ Storage conditions } & \multicolumn{4}{|c|}{ Research year and harvesting time } \\
\hline & & \multicolumn{2}{|c|}{$2012-2013$} & \multicolumn{2}{|c|}{$2013-2014$} \\
\hline & & $1^{\text {st }}$ harvesting & $2^{\text {nd }}$ harvesting & $1^{\text {st }}$ harvesting & $2^{\text {nd }}$ harvesting \\
\hline \multirow{4}{*}{ 'Auksis' } & cold storage & $30.00 \mathrm{aA}$ & $14.42 \mathrm{aB}$ & $100.00 \mathrm{aA}$ & $9.90 \mathrm{aB}$ \\
\hline & cold storage $+1-\mathrm{MCP}$ & $22.22 \mathrm{bA}$ & $2.08 \mathrm{bB}$ & $10.76 \mathrm{bA}$ & $6.31 \mathrm{bB}$ \\
\hline & ULO1 & $2.35 \mathrm{cA}$ & $100.00 \mathrm{cB}$ & $3.38 \mathrm{cA}$ & $4.05 \mathrm{cA}$ \\
\hline & ULO2 & $1.43 \mathrm{cA}$ & $1.87 \mathrm{bA}$ & $1.54 \mathrm{dA}$ & $2.35 \mathrm{~dB}$ \\
\hline \multirow{4}{*}{ 'Orlik' } & cold storage & $88.10 \mathrm{aA}$ & $100.00 \mathrm{aB}$ & $100.00 \mathrm{aA}$ & $100.00 \mathrm{aA}$ \\
\hline & cold storage $+1-\mathrm{MCP}$ & $30.95 \mathrm{bA}$ & $25.93 \mathrm{bB}$ & $100.00 \mathrm{aA}$ & $100.00 \mathrm{aA}$ \\
\hline & ULO1 & $5.51 \mathrm{cA}$ & $100.00 \mathrm{aB}$ & $5.16 \mathrm{bA}$ & $6.01 \mathrm{bB}$ \\
\hline & ULO2 & $2.33 \mathrm{dA}$ & $3.96 \mathrm{cB}$ & $3.57 \mathrm{cA}$ & $3.12 \mathrm{cA}$ \\
\hline \multirow{4}{*}{ 'Gita' } & cold storage & $100.00 \mathrm{aA}$ & $100.00 \mathrm{aA}$ & $100.00 \mathrm{aA}$ & $100.00 \mathrm{aA}$ \\
\hline & cold storage $+1-\mathrm{MCP}$ & $21.95 \mathrm{bA}$ & $100.00 \mathrm{aB}$ & $21.21 \mathrm{bA}$ & $18.38 \mathrm{bB}$ \\
\hline & ULO1 & $7.89 \mathrm{cA}$ & $100.00 \mathrm{aB}$ & $5.43 \mathrm{cA}$ & $6.26 \mathrm{cB}$ \\
\hline & $\mathrm{ULO} 2$ & $3.28 \mathrm{dA}$ & $5.85 \mathrm{bB}$ & $4.14 \mathrm{dA}$ & $5.32 \mathrm{~dB}$ \\
\hline \multirow{4}{*}{ 'Antej' } & cold storage & $24.24 \mathrm{aA}$ & $13.89 \mathrm{aB}$ & $19.23 \mathrm{aA}$ & $10.68 \mathrm{aB}$ \\
\hline & cold storage $+1-\mathrm{MCP}$ & $11.76 \mathrm{bA}$ & $5.56 \mathrm{bB}$ & $15.45 \mathrm{bA}$ & $6.36 \mathrm{bB}$ \\
\hline & ULO1 & $2.23 \mathrm{cA}$ & $3.21 \mathrm{cB}$ & $3.29 \mathrm{cA}$ & $3.91 \mathrm{cA}$ \\
\hline & $\mathrm{ULO} 2$ & $1.45 \mathrm{dA}$ & $2.58 \mathrm{~dB}$ & $1.89 \mathrm{dA}$ & $3.04 \mathrm{cB}$ \\
\hline \multirow{4}{*}{$\begin{array}{l}\text { 'Belorusskoje } \\
\text { Malinovoje' }\end{array}$} & cold storage & $39.02 \mathrm{aA}$ & $14.29 \mathrm{aB}$ & $28.35 \mathrm{aA}$ & $100.00 \mathrm{aB}$ \\
\hline & cold storage $+1-\mathrm{MCP}$ & $12.50 \mathrm{bA}$ & $9.30 \mathrm{bB}$ & $12.31 \mathrm{bA}$ & $13.05 \mathrm{bA}$ \\
\hline & ULO1 & $2.98 \mathrm{cA}$ & $100.00 \mathrm{cB}$ & $3.15 \mathrm{cA}$ & $100.00 \mathrm{cB}$ \\
\hline & ULO2 & $3.21 \mathrm{cA}$ & $6.18 \mathrm{~dB}$ & $2.19 \mathrm{dA}$ & $100.00 \mathrm{cB}$ \\
\hline \multirow{4}{*}{ 'Sinap Orlovskij' } & cold storage & $9.76 \mathrm{aA}$ & $6.50 \mathrm{aB}$ & $12.23 \mathrm{aA}$ & $5.51 \mathrm{aA}$ \\
\hline & cold storage $+1-\mathrm{MCP}$ & $4.08 \mathrm{bA}$ & $0.00 \mathrm{bB}$ & $5.32 \mathrm{bA}$ & $3.22 \mathrm{bB}$ \\
\hline & ULO1 & $0.00 \mathrm{cA}$ & $100.00 \mathrm{cB}$ & $0.00 \mathrm{cA}$ & $1.32 \mathrm{cB}$ \\
\hline & ULO2 & $0.00 \mathrm{cA}$ & $0.00 \mathrm{bA}$ & $0.00 \mathrm{cA}$ & $1.95 \mathrm{cB}$ \\
\hline \multirow{4}{*}{ 'Zarja Alatau' } & cold storage & $15.38 \mathrm{aA}$ & $15.33 \mathrm{aA}$ & $14.21 \mathrm{aA}$ & $100.00 \mathrm{aB}$ \\
\hline & cold storage $+1-\mathrm{MCP}$ & $15.79 \mathrm{aA}$ & $11.11 \mathrm{bB}$ & $9.82 \mathrm{bA}$ & $10.04 \mathrm{bA}$ \\
\hline & ULO1 & $100.00 \mathrm{bA}$ & $100.00 \mathrm{cA}$ & $5.65 \mathrm{cA}$ & $100.00 \mathrm{aB}$ \\
\hline & ULO2 & $4.65 \mathrm{cA}$ & $100.00 \mathrm{cB}$ & $5.01 \mathrm{cA}$ & $6.79 \mathrm{cB}$ \\
\hline
\end{tabular}

Notes. Means (percent of rotten apples) followed by different small letters within the same column and cultivar, are significantly different at the 0.05 level (differences between storage types). Mean (percent of rotten apples) followed by different capital letters within the same row and year, are significantly different at the 0.05 level (differences between harvesting time).

$N$. alba population seems to be sensitive to post-harvest treatment with thiabendazole (TBZ) fungicide (Spotts et al., 2009). However, due to toxicity of this compound, use of TBZ has been prohibited in the Baltic countries and in other countries of North Europe.

Recently, great interest has been shown by several scientists to hot water treatment as natural means to control fruit post-harvest decay. Evidence points that hot water treatment reduces the development of the following microscopic fungi: Botrytis cinerea, Penicillium spp., Mucor piriformis and Monilinia spp. (Neri et al., 2007; Sholberg, Randall, 2007; Mari et al., 2008), while significantly positive effect on the development of $N$. alba has not been achieved (Maxin et al., 2005).

During the experiment in $13.04 \%$ cases microscopic fungus Colletotrichum acutatum was isolated from damaged apples in cold storage (Fig. A).

Research results indicate that in $8.69 \%$ cases microscopic fungus Botrytis cinerea was isolated from damaged apples in cold storage as the only significant microorganism that potentially can cause the spoilage of fruits. Post-harvest losses caused by infection with $B$. cinerea can be reduced by minimising mechanical injury, maintaining fruits and vegetables in their early stages of ripening, storing them under optimal conditions, treating with antimicrobial agents. From the results obtained in the current research it is clear that apple samples that prior to storage had been treated with 1-MCP also were infected with microscopic fungi. The microscopic spectrum, isolated from the apples was not considerably different compared with the control fruits. For instance, microscopic fungus $P$. expansum was found in the same frequency as in the control $-35.26 \%$ and $30.44 \%$, respectively (Fig. B and A). In this treatment also microscopic fungus Fusarium avenaceum was found $(5.89 \%)$. To the best of our knowledge, this is the first report of Fusarium rot caused by $F$. avenaceum on apple fruit that prior to cold storage had been treated with 1-MCP in Latvia. Furthermore, compared with the cold storage the highest amount of microscopic fungus Colletotrichum acutatum (23.57\%) was found in this type of storage. The same results were obtained by the group of researchers Janisiewicz et al. (2003) pointing out that 1-MCP treatment increased bitter (C. acutatum) rot and blue mold ( $P$. expansum) decays. However, 1-MCP treatment was more effective compared with the application of antagonist and heat treatment (Janisiewicz et al., 2003). Figure (C and D) shows that in $33 \%$ cases microscopic fungus $N$. alba was isolated from infected tissue of apples that had been stored under controlled atmosphere conditions in ULO1 and ULO2.

It was estimated that in $26.69 \%$ (ULO1) and $33.33 \%$ (ULO2) cases microscopic fungus Monilinia fructigena was isolated from damaged apples. Furthermore, scientists (Karabulut, Baykal, 2004) argue that growth and development of this fungus can be maintained using fruit storage under optimal conditions in controlled atmosphere. Unfortunately, effectiveness of controlled atmosphere as a tool of reduction of microscopic fungus $M$. fructigena was not been proved.

One cause of the decay in apples stored under controlled atmosphere conditions in ULO was microscopic fungus Phomopsis/Diaporthe eres. Incidence of $P h . / D$. eres infection on apples stored in ULO1, was $6.66 \%$, while in ULO2 $16.67 \%$. Diaporthe spp. are responsible for diseases on a wide range of plant hosts, causing root and fruit rots, dieback, cankers, leaf spots, blights, decay and wilt (Thompson et al., 2011). Infection of microscopic fungus manifested itself as typical spores, whose development occur on the surface and can be isolated from pure culture. This microscopic fungus is a typical apple causal agent (Davidzon et al., 2010). The initial systematic infection usually occurs during apple flowering due to the fact that Phomopsis spp., advantageously colonise dead limbs and trunks. The first symptoms can be observed when apple is ready for use (Prusky et al., 2009).

Figure (C) shows that in $6.66 \%$ cases microscopic fungus Mucor circinelloides was isolated from damaged apples that had been stored under controlled atmosphere conditions in ULO1. Based on the research report provided by Gherbawy and Hussein (2010) it is evident that despite the use of advanced storage technologies 

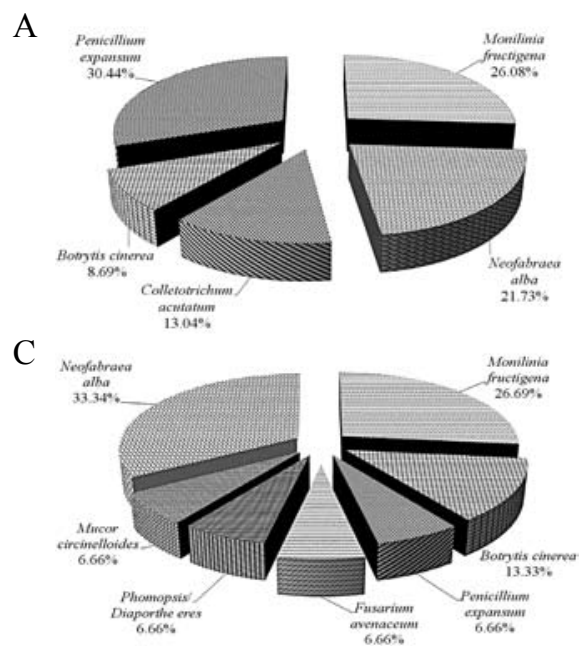

B

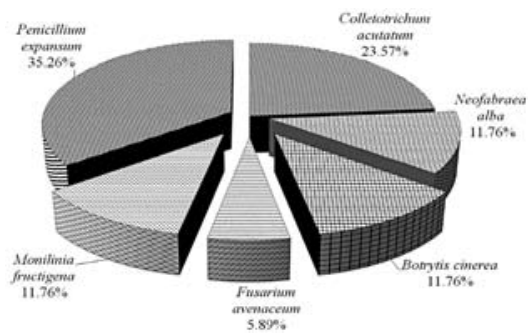

$\mathrm{D}$

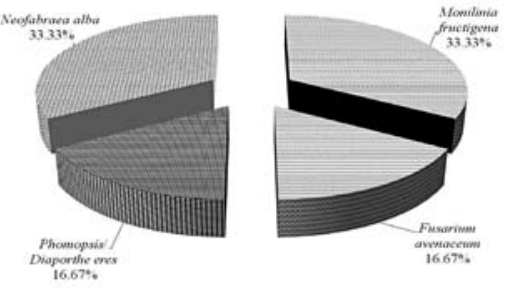

Note. A - cold storage (control), B - cold storage + 1-MCP treatment, C - ULO1, D - ULO2; data are expressed as the average for two research years, 2013 and 2014.

Figure. The spectra of isolated microorganisms from spoiled apples

and methods, the losses due to various postharvest diseases are estimated to range from $10-30 \%$ per year. Notwithstanding the fact that several scientists consider a microscopic fungus $M$. circinelloides as the main cause of apple spoilage, more detailed analysis of scientific papers indicated that the main cause of apple quality deterioration is associated with the microscopic fungus Mucor spp. that causes significant loss of apple yield during a long-term storage.

\section{Conclusions}

1. The average decay of apples stored in cold storage (control) was $48.96 \%$, while significant $(p<0.05)$ decrease was observed when apple samples prior to cold storage had been treated with 1-Methylcyclopropene (1MCP) - up to $21.62 \%$. In turn, the severity of decay of apples stored in ultra low oxygen ULO1 and ULO2 was $34.70 \%$ and $9.91 \%$, respectively.

2. The highest microbial diversity and amount on apples were found in the cold storage suggesting that these conditions were not suitable for long-term storage of apples. Storage of apple fruits in ULO2 with $2.5 \%$ $\mathrm{CO}_{2}, 1.5 \% \mathrm{O}_{2}$ appeared to be more promising for several commercial apple cultivars. In particular, cvs. 'Auksis', 'Orlik', 'Gita', 'Antej' and 'Sinap Orlovskij' showed the lowest spoilage rate.

3. The most prevalent microorganisms (cold storage) that were isolated from spoiled apples were: Penicillium expansum, Monilinia fructigena, Neofabraea alba, Colletotrichum acutatum and Botrytis cinerea, while isolated spectrum of microorganisms from the samples treated with 1-MCP was as follows: P. expansum, C. acutatum, $N$. alba, B. cinerea and $M$. fructigena. Microorganisms isolated from the surface of apples stored under ULO1 and ULO2 conditions were as follows: $N$. alba, M. fructigena, B. cinerea, $P$. expansum, Fusarium avenaceum, Phomopsis/Diaporthe eres and Mucor circinelloides. Microscopic fungus $F$. avenaceum was not found only on the surface of apples that had been kept under cold storage conditions. In turn, microscopic fungus of the genus $P h . / D$. eres was identified when apples had been stored under ultra low oxygen conditions.

\section{Acknowledgments}

This research has been prepared within National Research Programme No. 2010.10-4/VPP-5 "Sustainable use of local resources (entrails of the earth, food, and transport) - new products and technologies" (NatRes)
(2010-2013). National Research Programme No. 10-4/ VPP-7/3 "Agricultural Resources for Sustainable Production of Qualitative and Healthy Foods in Latvia" (AgroBioRes).

We are grateful to Latvian Plant Protection Research Centre for their cooperation, to Julia Volkova for help with sequencing analysis.

Received 22042016 Accepted 22082016

\section{References}

Barreira M. J., Alvito P. C., Almeida C. M. M. 2010. Occurrence of patulin in apple-based-foods in Portugal. Food Chemistry, $121(3) \cdot 653-658$

http://dx.doi.org/10.1016/j.foodchem.2009.12.085

Calvo G. LUIU. Antioxidant use in apple and pear storage. Part $1-$ Regulatory situation: Washington State University, Tree Fruit Research and Extension Center. http://www.tfrec.wsu.edu/ pdfs/P1280.pdf [accessed 0106 2016]

Davidzon M., Alkan N., Kobiler I., Prusky D. 2010. Acidification by gluconic acid of mango fruit tissue during colonization via stem and infection by Phomopsis mangiferae. Postharvest Rinlnoy and Terhnolnoy 55 (2). 71-77 http://dx.doi.org/10.1016/j.postharvbio.2009.08.009

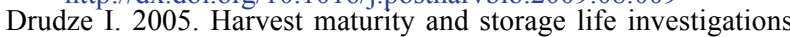
on Latvian apple cultivars. Latvian Journal of Agronomy, 8: 306-310

Ellis M. A. 2008. Bitter rot of apples. The Ohio State University Extension. Agriculture and Natural Resources, p. 1-3 http://www oardc. ohio-state.edu/fruitpathology/factsheets/HYG 330208 REV.pdf

Gherbawy Y. A., Hussein N. A. 2010. Molecular characterization of Mucor circinelloides and Rhizopus stolonifer strains isolated from some Saudi fruits Fondhorne Pathnoens and Disease, 7 (2): 137-142 http://dx.doi.org/10.1089/fpd.2009.0359

Janisiewicz W. J., William B. L. Conway S., Saftner K. A., Reed A. N., Camp M. J. 2003. Control of bitter rot and blue mold of apples by integrating heat and antagonist treatments on 1-MCP treated fruit stored under controlled atmosphere conditions. Postharvest Riology and Technology 29: 129-143 http://dx.doi.org/10.1016/S0925-5214(03)00040-1

Janisiewicz W. J., Kurtzman C. P., Buyer J. S. 2U10. Yeasts associated with nectarines and their potential for biological control of hrown rot. Yeast, 27 (7): 389-398 http://dx.doi.org/10.1002/yea.1763

Jemric D., Ivic G., Fruk H. S., Matijas B., Cvjetkovic M., Bupic B., Pavkovic K. 2011. Reduction of postharvest decay of peach and nectarine caused by Monilinia laxa using hot water dinning. Fond and Rionrocess Technology, 4 (1): 149-154 http://dx.doi.org/10.1007/s11947-010-0355-Z

Jönssson A., Nybom H., Kumpunen K. 2UIU. Fungal disease and fruit quality in an apple orchard converted from integrated production to organic production. Journal of Sustainable Agriculture and the Environment, 34 (1): 15-37 http://dx.doi.org/10.1080/10440040903396565

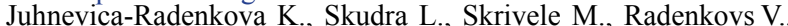
Seglina D. 2014. Impact of the degree of maturity on apple quality during the shelf life. Proceedings of $9^{\text {th }}$ Baltic conference on food science and technology Food for Consumer Well-Being Foodbalt 2014, p. 161-166 
Juhnevica-Radenkova K., Radenkovs V., Seglina D. 2016. Influence of 1-MCP treatment and storage conditions on the development of microorganisms on the surface of apples grown in Latvia. 7 emdirhycte-A griculture $103(2) \cdot 215-270$

http://dx.doi.org/10.13080/z-a.20́16.103.028

Juhneviča K., Skudra G., Skudra L. 2U11. Evaluation of microbiological contamination of apples stored at modified atmosphere. Environmental and Experimental Biology, 9 (1-2): 53-59

Karabulut O. A., Baykal L. N. 2004. Integrated control of postharvest diseases of peaches with a yeast antagonist, hot water and modified atmosphere packaging. Food and Rinnrocesc Technology $32(5) \cdot 431-435$ http://dx.doi.org/10.1016/j.cropro.2003.09.012

Liu J., Sui Y., Wisniewski M., Droby S., I1an S., Norelli J., Hershkovitz V. 2012. Effect of heat treatment on inhibition of Monilinia fructicola and induction of disease resistance in neach fruit Postharvest Rinlnov and Technolnov 65: 61-68 http://dx.doi.org/10.1016/j.postharvbio.2011.11.002

Mari M., Leoni U., Bernardi K., Neri F., Laimieri S. zUUx. Control of brown rot on stone fruit by synthetic and glucosinolate-derived isothiocvanates Postharvest Rinlnov and Technolnov 47 (1): 61-67 http://dx.doi.org/10.1016/j.postharvbio.2007.06.003

Maxin P., Huyskens-Keil S., Klopp K., Ebert G. 2UUS. Control of postharvest decay in organic grown apples by hot water treatment Acta Horticulturae 687. 2153-2158 http://dx.doi.org/10.17660/ActaHortic.2005.682.294

Neri F., Mari M., Menniti A. M., Brigati S., Bertolini P. 2007. Fungicidal activity of plant volatile compounds for controlling Monilinia laxa Plant Disease 91 (1) 30-35 http://dx.doi.org/10.1094/PD-91-0030

Neri F., Marı M., Brigatı S., Bertolını P. 2009. Control of Neofabraea alba by plant volatile compounds and hot water. Postharvest Rinlngy and Technolngy 51 (3): 425-430 http://dx.doi.org/10.1016/j.postharvbio.2008.08.006

Prusky D., Kobiler 1., Miyara 1., Alkan N. 2009. Fruit diseases. Litz R. E. (ed.). The mango, botany, production and uses ( $2^{\text {nd }}$ ed.) p. 210-231 http://dx.doi.org/10.1017/S0014479710000116
Sholberg P. L., Randall P. 2007. Fumigation of stored pome fruit with hexanal reduces blue mold and gray mold. HortScience, 42 (3): 611-616

Spadoni A., Neri F., Bertolini P. M. 2013. Control of Monilinia rots on fruit naturally infected by hot water treatment in commercial trials Postharvest Rinlogy and Technology, 86. 780-284 http://dx.doi.org/10.1016/j.postharvbio.2013.07.011

Spotts K. A, Seiter K. A, Wallis K. M., sugar D, Xia L. L., Serdani M., Henriquez J. L. 2009. Description of Cryptosporiopsis kienholzii and species profiles of Neofabraea in major pome fruit growing districts in the Pacific Northwest USA. Mvenlnoical Research 112 (11) 1 1201-1211 http://dx.doi.org/10.1016/j.mycres.2009.08.013

Tahir I. Zứ6. Controi of pre- and postharvest factors to improve apple quality and storability: Doctoral thesis, Swedish University of Agricultural Sciences. Uppsala, Sweden

Thompson S. M., Tan Y. P., Young A. J., Neate S. M., Aitken E. A., Shivas R. G. 2011. Stem cankers on sunflower (Helianthus annuus) in Australia reveal a complex of pathogenic Diaporthe Phomonsis) snecies Personnia 27.80_80 http://dx.doi.org/10.3767/003158511X617110

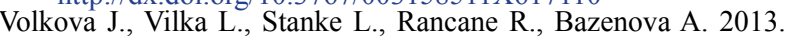
Molecular characterization of Monilinia laxa and Monilinia fructigena causing brown rot of sweet cherry in Zemgale region of Latvia. Acta Biologica Universitatis Daugavpiliensis, 13 (1): 177-184

Watkins C. B., Lui F. 2010. Temperature and carbon dioxide interactions on quality of controlled atmosphere-stored 'Empire' apples. HortScience, 45 (11): 1708-1712

Wawrzynczak A. Jozwiak Z, Rutkowski K. 2007. The influence of storage conditions and 1-MCP treatment on ethylene evolution and fruit quality in 'Gala' apple. Vegetable Crops Research Rulletin, 66: 188-196 http://dx.doi.org/10.2478/v10032-007-0021-9

Weber A. Brackmann A., Anese $\bar{K}$. U., Both V. , Pavanello E. P. 2011. 'Royal Gala' apple quality stored under ultralow oxygen concentration and low temperature conditions. Pesquisa Agropecuária Brasileira, 46 (12): 1597-1602

ISSN 1392-3196 / e-ISSN 2335-8947

Zemdirbyste-Agriculture, vol. 103, No. 4 (2016), p. 391-396

DOI 10.13080/z-a.2016.103.050

\title{
Mikrobiologiniai pokyčiai ir obuolių puvinio intensyvumas ilgą laiką skirtingomis sąlygomis laikytuose obuoliuose
}

\author{
K. Juhnevica-Radenkova, V. Radenkovs, D. Seglina \\ Latvijos žemès ūkio universiteto Sodininkystès institutas
}

\section{Santrauka}

Nors obuoliai užima didžiają dalị Latvijos daržovių rinkos, šalyje trūksta geros kokybės vietoje užaugintų obuolių. Pažangių sandèliavimo technologijų taikymas, pavyzdžiui, laikymas kontroliuojamoje atmosferoje esant itin mažai deguonies $\left(\mathrm{O}_{2}\right)$ koncentracijai ir padidintai anglies dioksido $\left(\mathrm{CO}_{2}\right)$ koncentracijai, taip pat prieš laikyma obuoliu apdorojimas 1-metilciklopropenu (1-MCP), gali smarkiai pagerinti vaisių kokybę ir padèti obuolių augintojams visame pasaulyje i rinka pateikti geresnès kokybès ir saugesnius vaisius. Tyrimo tikslas - nustatyti obuoliu puvinio priežastis, juos laikant ịvairiomis sąlygomis. Tirtos dvi obuolių laikymo technologijos: 1) laikymas šaltai esant iprastoms sąlygoms ir apdorous 1-metilciklopropenu, 2) laikymas kontroliuojamoje atmosferoje - 2,0\% $\mathrm{CO}_{2} 1,0 \%$ $\mathrm{O}_{2}$ (ULO1) bei $2,5 \% \mathrm{CO}_{2}, 1,5 \% \mathrm{O}_{2}$ (ULO2). Po 6 mènesių obuolius laikant šaltai buvo nustatyti šie mikroskopiniai grybai: Penicillium expansum (30,44 \%), Monilinia fructigena $(26,08 \%)$, Neofabraea alba $(21,73 \%)$, Colletotrichum acutatum (13,04\%), Botrytis cinerea (8,69\%). P. expansum (35,26\%), Colletotrichum acutatum $(23,57 \%)$, Neofabraea alba $(11,76 \%)$, B. cinerea $(11,76 \%)$, M. fructigena $(11,76 \%)$ ir Fusarium avenaceum $(5,89 \%)$ buvo išskirti iš obuolių, kurie prieš laikymą buvo apdoroti 1-MCP. Obuoliai, laikyti ULO1 sąlygomis, buvo labiausiai užsikrètę $N$. alba $(33,34 \%)$, M. fructigena $(26,69 \%)$, B. cinerea $(13,33 \%)$, P. expansum $(6,66 \%), F$. avenaceum (6,66\%), Phomopsis/Diaporthe eres (6,66\%), Mucor circinelloides $(6,66 \%)$, o laikyti ULO2 sąlygomis - N. alba $(33,33 \%)$, M. fructigena $(33,33 \%)$, F avenaceum $(16,67 \%)$ ir P./D. eres $(16,67 \%)$. Mikroskopiniu grybu, išskirtų iš nevienodomis sąlygomis laikytų puvinio pažeistų obuolių, įvairovè yra gana panaši. Tačiau mikroskopinis grybas $F$. avenaceum nebuvo rastas tik šaltai laikytuose obuoliuose, o mikroskopinis $P$./D. eres genties grybas buvo nustatytas, kai obuoliai laikyti esant itin mažai deguonies koncentracijai.

Reikšminiai žodžiai: kontroliuojama atmosfera, 1-metilciklopropenas, mikrobiologinis užterštumas, obuolių vaisiai, veislè.

Please use the following format when citing the article:

Juhnevica-Radenkova K., Radenkovs V., Seglina D. Microbiological changes and severity of decay in apples stored for a long-term under different storage conditions. Zemdirbyste-Agriculture, 103 (4): 391-396 DOI $10.13080 / \mathrm{z}-\mathrm{a} .2016 .103 .050$ 